\title{
Do Values Relate to Personality Traits and if so, in What Way? - Analysis of Relationships
}

\section{Mirosława Czerniawska (DD Joanna Szydło (1D}

Faculty of Engineering Management, Bialystok University of Technology, Bialystok, Poland
Correspondence: Joanna Szydło Wiejska Street 45A, Bialystok, I5-35I, Poland

$\mathrm{Tel}+48662321638$

Email j.szydlo@pb.edu.pl
Introduction: The research presents empirical data concerning the relations between personal traits and value system. The study focuses on empathy, agreeableness, directiveness, Machiavellism as personality traits. Theoretical assumptions and empirical findings are analyzed and interpreted in the context of cognitive framework, including the idea of regulative function self-concept. A content compatibility hypothesis between personality traits and one's system of value was accepted as preliminary assumption for this research: empathy and agreeableness positively correlate with allocentric values, whereas directiveness and Machiavellism positively correlate with idiocentric values. The study group consisted of 325 students.

Methods: The Empathic Understanding of Others Questionnaire (Węgliński), Personality Inventory NEO-FFI (Costa and McCrae) Directiveness Scale (Ray) and Mach V Scale (Christie and Geis) were used.

Results: The value system of empathic and agreeable people reveals an allocentric orientation (tendency to abandon one's own perspective), while the value system of directive and Machiavellian people reveals an idiocentric orientation (focused on oneself).

Discussion: The data analysis revealed that subjects tend to organize their self-knowledge in such a way that there is a content consistency between the information included in the appropriate schemas of personality traits and value preference.

Keywords: value, personality traits, empathy, agreeableness, directiveness, Machiavellism, self-concept

\section{Introduction}

Social sciences attach great importance to values as constructs that help to understand human attitudes, views, norms and behaviour. In the $1950 \mathrm{~s}$, Allport ${ }^{1}$ pointed out that an individual's preferable values direct their behaviour, while priorities within values influence the perception of reality. At a later time, the key role of values in giving meaning to single acts and creating a vision of the world was emphasized by Rokeach $^{2,3}$ and Schwartz. ${ }^{4,5}$ Such views are widely documented in the literature. ${ }^{6-8}$

If values are assigned such a large role in the perception of the world and the determination of human behaviour, the following question becomes relevant: what factors determine their hierarchy? What an individual considers valuable is a consequence of their choices. Furthermore the choice of values is conditioned by geographical, climatic, political, economic, historical and legal variables. It depends on cultural, institutional and personality factors. ${ }^{3,9-15}$ The relationship between values and personality traits will be the subject of empirical consideration. The article uses some of the data from previous publications. ${ }^{16-18}$ 


\section{An Analysis of Relations Between Personality Traits and Values}

Personality is understood as characteristic patterns of thoughts, feelings and actions which result in specific ways of interacting with the environment. ${ }^{19}$ One of the concepts of personality is the trait theory. Traits are "psychological entities that can only be inferred from behaviour and experience". ${ }^{20}$ They are considered to be the basic components of personality that foster the characteristics of an individual. They serve to clarify observed regularities and the consistency of behaviour and differences among people. Whereas values are most often interpreted as abstract concepts or beliefs (cognitive structure) which refer to preferable end-states of existence or modes of behaviour. They are organized according to the scale of their relative importance and they are transcendent in relation to the situation. They guide the evaluation and selection of specific behaviour. If values are in conflict, a person tends to behave according to the one that occupies a higher position in the hierarchy. ${ }^{2,5,9}$ What are the similarities and differences between personality traits and values? Are they and how are they related to each other?

According to Dollinger et $\mathrm{al}^{21}$ personality traits and values reveal themselves in the functioning of a person in many situations throughout their life. This fact lies at the core of expectations about their mutual dependence. Both constructs are similar in the sense that they direct the emergence of stable differences in human behaviour ${ }^{22}$ although personality affects behaviour not as strongly as values $^{23}$.

There are much more differences between the two constructs. Personality traits are stable dispositions; they describe "what people are like" and they are not always associated with the excitation of motivational tension. Values are also stable but they determine what goals people want to achieve and what behaviour they consider appropriate. The motivational aspect is therefore clearly emphasized. Personality traits guide behaviour but do not constitute their standard. Rather, they are associated with a natural tendency to a certain type of reaction. Values, on the other hand, provide standards in the choice of behaviour. People can explain their behaviour by referring both to traits and values, but only values contain the evaluation component. Therefore, they - not traits - serve to evaluate and justify one's behaviour and that of others. ${ }^{5,11,24}$

Values include the conflict element, ie some are realized at the expense of others, while personality traits are not organized on such a basis, for example, one can express extraversion and agreeableness at the same time. ${ }^{25}$ This is because values differ in importance, ie relative preference with regard to one another within the system, whereas personality traits vary in intensity and frequency of occurrence. Without creating a system, traits may be independent of each other. The manner in which the two constructs are measured is also different: values emphasize the importance of each of them for the Self, personality traits take into account beliefs about one's self. Furthermore, traits can be positive and negative, values as desired states - only positive..$^{24,26}$

Personality traits are considered to be rather inborn constructs. ${ }^{27}$ Values, on the other hand, are of learned nature, ie they constitute beliefs that reflect an individual's adaptation to the needs accepted by the society. ${ }^{2}$ As Parks and Guay ${ }^{25}$ indicate, individuals behave in an extravert way (personality) since being an extravert is part of their nature. An individual behaves in honest way (value) because he or she has learned that honesty is important. However, the proportions of what is genetic, cultural, and environmental in both constructs are not entirely determined. Furthermore, the value system is relatively more dynamic than personality traits. It can change when an individual adapts to their new environment. ${ }^{2}$ Personality traits are characterized by greater durability during life, ${ }^{25,28}$ as evidenced by high - equalling 0.98 - stability coefficients. ${ }^{25}$

However, in practice it can be difficult to make distinctions between the analysed constructs. Roccas et $\mathrm{al}^{26}$ indicate that the same terms can refer to both personality traits and values. For example, "competence" may refer to "being competent" (trait) as well as a conviction that the pursuit of competence and its presentation are important (value). However, it is not always the case that someone who has competency in a certain area is convinced that it is a value. It is also sometimes the case that competence is valued without having it in any area of one's functioning.

\section{Research on Personality Traits and Values - an Overview}

In theoretical considerations, the prevailing view is that personality traits and values are two separate constructs which influence behaviour in an interactive manner. ${ }^{1}$ This does not mean, however, that they are not correlated with each other. The results of research conducted by Oles ${ }^{29}$ point to the content-related compatibility of personality 
traits (diagnosed by means of Cattell's 16 Personality Factor Questionnaire) with value preferences. The author observed that the values that are particularly highly accepted are the ones that an individual can realize relatively easily, because they are in line with personality traits. This regularity was also confirmed in other studies. They showed, for example, that extraversion (measured with Eysenck Personality Test) is associated with a higher preference for values connected with contacts with other people, ${ }^{30}$ intelligence - with higher preference for cognitive values ${ }^{30,31}$ (the research incorporated the Rokeach Value Survey). Also Bilsky and Schwartz ${ }^{24}$ described important relations between personality traits (extraversion and emotionality, diagnosed with the Freiburg Personality Inventory) and value preference (Rokeach Value Survey).

A relatively large number of studies on the identified problem refer to the Big Five theory ${ }^{21,26,28,32-38,39}$ and use Costa and McCrae's NEO-PI or NEO-FFI Five Factor Inventory. They diagnose five basic personality traits: neuroticism (emotional stability-instability), extraversion (quality and intensity of human interactions), openness to experience (looking for new experiences for oneself), agreeableness (interpersonal relations in the compassionhostility dimension) and conscientiousness (an individual's organization, persistence and motivation in pursuit of the goal). The meta-analysis of the results - conducted by Parks et al - at first based on eleven ${ }^{25}$ and subsequently sixty $^{40}$ studies - confirmed the theoretical assumptions concerning the relation between the above mentioned personality traits and values. The values were diagnosed with the use of the Schwartz Value Survey and incorporated references to the model created by this author, the socalled values circumplex model. According to this model, the values and the types determined on their basis can be located in two bipolar dimensions: ${ }^{5}$

- conservatism - openness to change;

- self-enhancement - self-transcendence.

The first of these dimensions reflects a conflict between the pursuit of stability and the cultivation of traditions (submissive self-limitation) and the pursuit of change and a high value of autonomy manifested in the independence of thinking and acting. The second dimension reflects a conflict between focusing on oneself and concentrating on others. Concentration on oneself is associated with selfpromotion, pursuit of dominance and focusing one's activity on personal success. Focusing on others requires abandoning the egocentric perspective, taking into account the well-being of the other person and promoting their well-being.

The two dimensions described above include certain types of values. And so, "universalism" and "benevolence" are components of the "self-transcendence" dimension, whereas "power" and "achievement" comprise the "self-enhancement" dimension. The "conservatism" dimension encompasses: "tradition", "conformity" and "security", whereas the "openness to change" includes "stimulation" and "self-direction". "Hedonism" belongs to two dimensions: "openness to change" and "selfenhancement". 9

In the light of the meta-analyses made by Parks et al, ${ }^{25,40}$ the values most frequently and most strongly correlated with two traits: openness to experience and agreeableness. The trait openness to experience was positively related to the following types of values: "self-direction", "stimulation", "universalism", and negatively with such types of values: "tradition", "conformity" and "security". Positive correlation coefficients were observed for agreeableness with the following types of values: "benevolence", "universalism", "conformity", "tradition", and a negative correlation coefficient with the "power" type of values. According to the authors, these relations reflect the sense of the analysed constructs. In the context of the trait openness to experience, people are described as independent and inner-directed, curious about the world, creative, open to new ideas and striving for wisdom and understanding of the world. It is compatible with the types of values "self-direction", "stimulation" and "universalism". Agreeable people are friendly, loyal, cooperating, supporting each other. The importance of the values "benevolence" and "universalism", on the other hand, is associated with the conviction that people strive to become honest, friendly and helpful. The values of "conformity" and "tradition" contribute to reduction of impulsiveness and facilitate community life. In case of conscientiousness and extraversion, weaker correlations with values were observed. Nevertheless, conscientiousness was positively related to the types of values: "conformity", "achievement" and "security", and extraversion - with types of values: "stimulation", "achievement", "power", and "hedonism". Neuroticism turned out to be a trait poorly related to values.

Parks-Leduc et $\mathrm{al}^{40}$ observed that "the strength of relations between traits and values should also be somewhat determined by content similarity when comparing 
each trait with each value" (p. 6). Moreover, they claimed that more cognitively based traits are more strongly related to values and more emotionally based traits are less strongly related to values. A similar opinion was presented by Zilling et al. (in: Grankvist, Kajonius) ${ }^{41}$ : the personality trait openness to experience (more cognitive) shows stronger links to values than neuroticism (more emotional).

The results described above are generally consistent with empirical data from the work by Roccas et $\mathrm{al}^{26}$ which was used to determine the compatibility of personality traits and value types. Nevertheless, in some cases the authors observed no compatibility. This was revealed, for example, in relation to the trait openness to experience and the value "power". The research by Roccas et al ${ }^{26}$ was conducted in Israel, but it was replicated in other countries, such as Sweden. Grankvist and Caionius ${ }^{41}$ claim that "traits and values are different constructs and that their relationship is consistent across the two geographic locations and student cohorts" (p. 8).

A lack of content-based consistency between personality traits and values was previously found in the research carried out by Furnham ${ }^{42}$ in which the Eysenck Personality Test was incorporated. The author pointed out that a person can also hold those values which he or she is not able - due to their individual traits - to realize. For example, an emotionally unstable person considers "internal harmony" an important value, a person with low self-esteem - "social recognition". According to Adler's views, ${ }^{34}$ sometimes people may hold values opposite to their personality traits, compensating for the latter. Saroglou and Muñoz-García ${ }^{43}$ observed that personalityvalues associations are usually modest. One reason for this discrepancy - to their view - may be the fact that people do not always hold values that correspond to who they are.

A comprehensive description of personality requires "something" more than three (Eysenck's personality theory) or five factors (Costa and McCrae's personality theory). Other personality traits and their relationship to values were also an interesting field of study. Balliet et $\mathrm{al}^{22}$ analysed empathy. The hypothesis that this trait correlates most positively with the "benevolence" value type was confirmed, which has a clear theoretical justification. However, the hypothesis that empathy correlates most negatively with the "achievement" value type was not confirmed. Such correlations were observed with the "power" value. In general, the correlation pattern between empathy and the ten types of values from the Schwartz model was in line with the predictions. The relationship between emotional empathy and values was also investigated by Myyry et al. ${ }^{44}$ Their work resulted in the confirmation of the hypotheses that this trait positively correlates with the type of values "benevolence" and "universalism" as those the realization of which expresses concern for the well-being of people in the immediate vicinity and people "in general". Later, the author ${ }^{45}$ pointed out the relationship between values and various aspects of empathy, treating them as predictors of the level of developing moral judgments (Kohlberg's cognitive developmental approach). Relationships between empathy and values were also studied by Persson and Kajonius. ${ }^{46}$ They observed that empathy was strongly and positively related to altruistic values and negatively to self-enhancing values.

Silfver et $\mathrm{al}^{47}$ drew attention to the role of emotions such as empathy, guilt and shame. They assumed that moral emotions and moral values are linked, while a description of these relationships will help to understand motivation. It appeared that guilt was positively correlated with such types of values as "universalism", "benevolence", "tradition", "conformity" and negatively with the types of values: "power", "hedonism", "stimulation" and "autonomy". The relationship with the two components of empathy was similar: empathic concern and perspective taking (the description of the components of empathy will be presented later in this paper). Shame and personal distress (personal distress is the third component of empathy) were weakly linked with values. In general, the values belonging to the dimensions of "self-transcendence" and "conservatism" are associated with pro-social tendencies, while the values belonging to the dimensions of "selfenhancement" and "openness to experience" are not (cf. Schwartz's values circumplex model described above).

\section{Personality Traits and Values from the Point of View of the Cognitive Self-Concept}

The analysis of the above dependencies leads to the question about the mechanism thanks to which specific relations between personality traits and values appear. The explanation of this mechanism allows for a more integrative understanding of a person.

According to the assumptions of the cognitive selfconcept, man makes a mental self-representation. This leads to the creation of rich and varied knowledge components. Examples of such components are beliefs about 
specific attributes, ie physical characteristics, personality traits, thinking, feelings, as well as roles, standards, values, personal goals, relations with other people. ${ }^{48-51}$ They constitute contents of the self-concept. Relationships between these constructs are formed in the course of one's life: as one acquires the ability to analyse oneself, the construction of the self-concept becomes more and more clearly and confidently defined, internally consistent, and stable over time. The so-called "self-concept clarity" belongs to a class of constructs that focus on the structural aspects of the self-concept (how the knowledge components or specific self-beliefs are organized). Crocetti and Van Dijak $^{52}$ made a review of the literature and the results of research conducted by many authors. They claimed that high levels of self-concept clarity have been found to be positively related to the perception of meaning in life and affect balance. It is also an indicator of healthy self-development and psychosocial adjustment.

It should be noted that the Self as a psychological construct includes, among other things, a self-representation of one's personality traits and a hierarchy of values. In the same people, information contained in cognitive schemes "personality traits" and "values" should be linked particularly strongly, as it is an important aspect of the self-concept. The mechanism underlying this relationship is based on the motivation to maintain self-esteem (striving for a positive Self). It turns out that people with a high sense of values articulate beliefs about the Self well, and thus are characterized by high levels of self-concept clarity. People with low self-esteem, on the other hand, are characterized by a relatively higher level of indeterminacy, instability and inconsistency. ${ }^{50,53-55}$ Differences in self-evaluation are related, among other things, to the degree of specifying relations between different elements of knowledge contained in the self-concept. ${ }^{56-62}$ Undoubtedly, self-esteem should not be taken as the only mental representation of a person's self-concept. ${ }^{63}$

If there is a merit-based correspondence between personality traits and values (ie two important components of knowledge about the Self), the chances of realizing these values increase. For example, "an exciting life" is more likely to be realized by an extrovert than an introvert person. Behaviour consistent with one's held values, in turn, contributes to strengthening self-esteem. ${ }^{2}$ The organization of knowledge about the Self, in which the acceptance of values being in opposition to personality traits is revealed, may result in low self-esteem. The lack of compatibility between these constructs significantly limits the possibility of achieving what it is considered valuable from an axiological point of view. Such dependencies appear most often in the case of values the realization of which depends on satisfying important needs, eg the need for security. The deprivation of these needs is revealed in the form of the so-called "no-value". Oleś ${ }^{29}$ showed that people with emotional disintegration, a stronger inclination to blame and a greater internal tension highly appreciated the value of "inner harmony".

\section{Research Problem and Hypotheses}

This paper attempts to characterize value systems in the context of personality variables, ie empathy, agreeableness, directiveness and Machiavellianism. The authors were particularly interested in the extent to which these constructs are integrated. Bearing in mind that both personality traits and values are organized in the self-concept, it should be expected to find many logical connections between them. To address this problem, personality traits need to be characterized in order to capture similarities in the content of particular traits and values.

\section{Empathy}

Empathy is interpreted as a multidimensional construct in its nature, containing both emotional and cognitive components. ${ }^{64-68}$ Emotional components are expressed in an empathic concern which leads to concentration on the other person's misfortune and attempts to restore their well-being, and in personal distress which, in turn, is oriented towards the Self and bringing relief in one's own suffering. The inclination to experience empathic concern and personal distress is conceptualized as personality traits. Nevertheless, the former leads to a constant altruistic motivation that increases social competence, while the latter leads to a constant egoistic motivation that decreases these competences. The cognitive component of empathy, defined as perspective taking, refers to the ability to see the world through the eyes of another person, to imagine what he or she feels in a particular situation. The dispositionally conditioned tendency for perspective taking makes it possible to generate empathic emotions which in turn direct the need for giving aid. ${ }^{67,69-75}$

Empathy emerges in the early stages of ontogenetic development (already an infant may exhibit instinctive help in the misery of others) and is conditioned by genetic factors and childhood experiences. ${ }^{76,77}$ Only the affective components of empathy are inherited: the tendency to 
experience empathic concern and personal distress. ${ }^{78}$ As Eisenberg et al. ${ }^{79,80}$ evidenced, individual differences in empathic tendencies are determined by emotional sensitivity and reactivity, which in turn are associated with hereditary (to a large extent) temperamental properties. ${ }^{78}$ Temperament determines dispositional emotional empathy, but not the aptitude for perspective taking. In the development of empathy, the history of the child-parent relationship is also important. Children learn empathy and prosocial reactions from observing their parents' emotions. ${ }^{81}$ Early experiences, including the attachment of infants to their parents, allow to transfer feelings and expectations to later social relationships. ${ }^{81,82}$

The research on prosocial behaviours has led to the formulation of the empathy-altruism hypothesis. Empathic people are more likely to offer help (and this help is selfless, motivated by concern for the well-being of the other person, "more delicate and less capricious") and less inclined to manifest aggression or other antisocial behaviour as well as show an increased interest in cooperation in conflict situations. ${ }^{83}$ Empathic people are more tactful, they communicate better with others, show tolerance to different social groups, see others more positively and express sympathy for the social environment. ${ }^{78}$ Empathy is considered in the context of moral principles - ie concern and justice - and analysed in the process of moral development. ${ }^{84}$

\section{Agreeableness}

Agreeableness is one of the traits included in the FiveFactor Model of Personality. According to the assumptions of Costa and McCrae, ${ }^{85-87}$ these traits determine the existence of individual differences between people. They are largely biological (to a large extent inherited), relatively unchanging (stable throughout life) and universal (similar features are found in different cultures and languages). They exert an overwhelming influence on human life by directing perceptions, thinking, feeling and behaviour.

Agreeableness concerns the trait of an individual's interpersonal references on a continuum from compassion to antagonism in thoughts, feelings and acts. Those who achieve high scores in agreeableness tend to be good, obliging, friendly, delicate, gentle, modest, straightforward, willing to give in and cooperate. They are characterized by trust and sensitivity to other people, concern for their interests and altruistic attitude.

The results of empirical research indicate that people with high agreeableness levels, compared to people with low agreeableness levels, are more positive about people and have a more positive opinion of their partners in interaction when it comes to experimental situations, show a lower level of prejudice (eg to obese people) and negatively evaluate such prejudice. They are characterized by empathy, see themselves as more similar to others and are able to solve conflicts constructively. They offer help more often (regardless of the intensity of the evoked empathy during the study), and this fact is less dependent on their kinship. In general, agreeableness is related to the desire to belong to others, it affects the motivation and behavioural strategies in different social situations. ${ }^{88,89}$

Agreeableness plays a role in regulating negative emotions, especially in situations of danger. Its higher rates are associated with a lower probability of depressive symptoms and lower levels of anger and aggression (and above all direct aggression). This helps to maintain positive interpersonal relationships and eliminate interpersonal conflicts. ${ }^{90,91}$ Agreeableness has been found to be substantially related to empathy, ${ }^{92,93}$ allows not only to predict pro-social attitudes, ${ }^{23,88}$ but is also associated with work ethic $^{94}$ and - what is more interesting - with achievements in learning. ${ }^{95}$

\section{Directiveness}

The concept of directiveness originates from the interest in the issue of authoritarianism. Ray ${ }^{96,97}$ claims that one should distinguish the notions of "authoritarian attitudes" (an attitude characterized by respect for authorities) and "authoritarian personality" (a personality trait related to the tendency to dominate over others). The latter term is associated with "directiveness" and, according to the author, these terms can be used interchangeably.

Directiveness - according to Ray ${ }^{97}$ - is a personality trait that comes down to imposing one's will on people and thus gaining an advantage over them. At its base lies the belief in the rightness of one's own conduct (self-confidence). The constitutive feature of directiveness is aggressive dominance. By dominating the social environment, such people are inclined to destroy positive interpersonal relations.

Dominance orientation means the degree to which a person wishes to surpass others (individual dimension) or the degree to which a person wishes his group to surpass others (social dimension). There is an acceptance of such a hierarchy among people whose values are in line with the principle "better people deserve more". People with a tendency to dominate show hostility, are more 
prone to stereotypes and prejudices and have a weaker tolerance for ambiguity, ie they react poorly to unclear situations. At the same time, they are in favour of aggressive resolution of international conflicts and large military expenditures. $^{98-100}$ A higher level of dominance orientation was found in feminists than in non-feminists, ${ }^{101}$ in men than women (in all social strata and all cultures), in educated people with higher social status, ${ }^{97,102}$ and who are highly motivated in their achievements. ${ }^{103}$ The propensity for dominance correlates negatively with the scale of social approval and the scale of socialization. On the other hand, the research on directiveness and value system (in Scheler's framework) indicates that high intensity of directiveness is coupled with higher preference for values of pleasure and lower preference for values of the spirit and values of the holy. ${ }^{97}$

The functioning of people with a high degree of directiveness has certain consequences in the interpersonal dimension. Dominance and aggression - as one might think - limits or even inhibits human pro-community aspirations based on equality, where understanding and acceptance of other people and the pursuit of acts for their benefit (pro-social behaviour) become important elements. It is less likely to build close emotional ties, connected with friendship, love and affection.

\section{Machiavellianism}

Machiavellianism is one of the three traits - along with narcissism and psychopathy - that constitute the dark triad of personality. ${ }^{104-106}$ This term has become synonymous with cunningness, deceitfulness, falsehood and doubledealing. Machiavellists believe that others should be manipulated and believe in the effects of such treatments. ${ }^{107-109}$ They are primarily aimed at success, ${ }^{110}$ a success that allows to gain prestige and present narcissistic grandeur, manifesting both superiority and arrogance, as well as the need for the title. Achievements are considered mainly in individual and material terms. ${ }^{111}$ Machiavellianism is associated with the pursuit of the manifestation of power ${ }^{112}$ and the need for dominance. ${ }^{113}$

The specificity of this type of personality is reflected both in the affective and cognitive sphere. Interpersonal relations do not evoke adequate emotions, in terms of content and intensity. Positive emotions are rare, while indifference or even emotional coolness is dominant. ${ }^{113}$ Machiavellists are not community-oriented and maintain a distanced attitude towards others. They have been found to exploit groups and defect from them afterward to avoid retaliation. ${ }^{114}$ They are characterized by the ability to efficiently decode other people's emotional states, but this has no empathic or decentrational consequences: The Machiavellian "rudeness" manifests itself in a reduced capacity for compassion and the inability to accept someone else's perspective. People are perceived by them in a suspicious and cynical way as weak, untrustworthy and prone to betrayal. ${ }^{108,115,116}$

Such Machiavellian traits as resistance to external influences and emotional coolness, favour rationality and unprecedented cognitive control over the environment. Machiavellists are well established in reality and rarely show signs of disorganization. Their cognitive effectiveness, manifested by concentration of attention, accuracy of perception, ability to process and use information, also deserves attention. Efficient combinations of information processes determine intelligent and adequate behaviour. ${ }^{111,112,117}$

The properties presented above stimulate the need for success and condition its realization. Undoubtedly, success is more obtainable when the perspective of another person is not taken into account, but it is considered from the point of view of its usefulness in achieving one's goals. What can potentially protect other people from abuse and manipulation are moral values, because their function is to take into account the extra-personal good. Machiavellists implement moral values selectively as long as they do not interfere with their own interests. They often violate the prevailing norms and show indifference in their thinking and acting to conventional morality. The pursuit of success plays a major role, and the question of how to achieve the goals seems to be of little importance. ${ }^{108,118,119}$

The above passages present the characteristics of four personality traits. As can be seen, they play a role in determining the relationship between Self and Others. Two of them - empathy and agreeableness - lie at the basis of constructing mature interpersonal relationships and generating positive behavioural intentions. They encourage pro-social behaviour aimed at the well-being of other people, as well as the suppression of anti-social behaviour addressed against the environment. In the case of the other two traits - directiveness and Machiavellianism - it is typical to focus on one's own person, pursue one's personal interests, without regard for the welfare of other people, and even against their good. Values are also classified according to the criterion "promotion of other people's well-being - promotion of one's own well-being". It is then possible to describe their 
differentiation in the dimension of allocentrism - idiocentrism. This dimension is identical to the collectivism individualism dimension, where in the first case the differentiation is analysed at the level of personality, in the second case at the level of cultures. ${ }^{4,9,120}$ Allocentric values direct the focus on interpersonal relationships and are morally relevant. They are connected with concern for others, pursuit of cooperation, equality and honesty. Idiocentric values, on the other hand, contribute to personal achievement and manifest themselves in a tendency to compete. They are connected on the one hand with independence and hedonistic striving, and on the other hand, with interest in the world and the need for cognitive development.

This study expects to uncover characteristics in the axiological dimension with persons differing in the intensity of empathy, agreeableness, directiveness and Machiavellianism, such that are consistent with the definition of personality. The search for relations between personality and value preferences is connected with the assumption that the functioning of a person constitutes psychological whole and the fact that various elements concerning oneself enter into relations during the creation of the self-concept. ${ }^{121,122}$ The verified hypotheses assume that:

Hypothesis 1: Empathy and agreeableness correlate positively with allocentric values and negatively with idiocentric values.

Hypothesis 2: Directiveness and Machiavellianism correlate positively with idiocentric values and negatively with allocentric values.

\section{Method}

Study design: The survey was questionnaire-based (5 questionnaires). This made it possible to collect data on four personality traits and a value system.

Research group: The study was conducted among 325 people. The age of the respondents was between 20-24 years (average age indicator $\overline{\mathrm{x}}=21.02$, standard deviation $\mathrm{s}=0.48$ ). The survey was carried out in Poland and was anonymous.

Material: The value preferences were determined with the use of the Rokeach Value Survey in a version requiring the formulation of a ranking. ${ }^{123}$ The author selected 18 terminal values and 18 instrumental values, placing them on two separate scales. Terminal values refer to desirable end-states of existence (how we like the world to be and where we would like to end up). Instrumental values refer to preferable modes of behavior (how we want to live in our life). The respondents' task was to order their values by assigning appropriate ranks, where rank 1 indicated the strongest acceptance of values and rank 18 - the weakest. On the basis of literature analysis it was proposed to divide 36 values in the Rokeach Value Survey into allocentric and idiocentric ones (justification for the division in: Czerniawska $^{124}$ ).

Allocentric values were associated with:

- protecting the well-being of all people and those with whom an individual enters in direct interaction (the welfare of the group to which an individual belongs): "a world at peace" (t17), "equality" (t2), "helpful" (i8), "honest" (i9), “forgiving” (i7), "loving” (i14), "responsible" (i17);

- security of identity groups and respect for tradition/ religion: "family security" (t4), "national security" (t9), "salvation" (t11);

- balanced social views, intrapersonal and interpersonal harmony: "wisdom" (t16), "inner harmony" (t7), "self-controlled" (i18), "clean" (i5), "polite" (i16), "obedient" (i15), "mature love" (t8), "true friendship" (t15).

Idiocentric values were associated with:

- social status, prestige and personal (including material) success: "social recognition" (t14), "selfrespect" (t12), "a sense of accomplishment" (t13), "ambitious" (i1), "a comfortable life" (t1);

- freedom of choice, independence of thought and action, intellectual competence: "freedom" (t5), "independent" (i11), "courageous" (i6), “imaginative" (i10), "broad-minded" (i2), "capable" (i3), "intellectual" (i12), "logical" (i13);

- hedonism and the need for stimulation (interesting, pleasant, varied life): "happiness" (t6), "cheerful" (i4), "pleasure" (t10), "an exciting life" (t3), "a world of beauty" (t18).

The personality traits were diagnosed using:

- empathy - the Questionnaire of Empathetic Understanding of Other People by Węgliński. ${ }^{125}$ The indicators range from 0 to 99 , with 0 being the 
minimum intensity of the trait and 99 being the maximum intensity of the trait;

- agreeableness - the Personality Inventory NEO-FFI by Costa and McCrae. ${ }^{126}$ The indicators range from 0 to 48 , with 0 being the minimum intensity of the trait and 48 being the maximum intensity of the trait;

- directiveness - the Directiveness Scale D-26 by J.J. Ray. ${ }^{97}$ The minimum number of points that surveyed person may obtain is 26 , the maximum - 78;

- Machiavellianism - the Mach V Scale by R. Christi and F.L. Geis. ${ }^{110}$ The indicators range from 40 to 160 points.

Each of the tools used in the research was developed from a psychometric point of view. Detailed information can be found in publications by the following authors: Brzozowski (1989; Rokeach Value Survey), Węgliński (1987; the Questionnaire of Empathetic Understanding of Other People by Węgliński), Drwal, Brzozowski (1995; the Mach V scale by R. Christi and F.L. Geis), Brzozowski (1997; the Directiveness Scale D-26 by J.J. Ray) and Zawadzki et al (1998; the Personality Inventory NEOFFI by Costa and McCrae).

Procedure: The survey was conducted during a 2.5-hour meeting (groups of 20-30 persons). The respondents answered the questions in the questionnaires. Handing out of the next questionnaire was preceded by a 15-minute break. The survey was anonymous and participation - voluntary.

Statistical analysis: The following information was obtained for each of the respondents:

- preference indicators for 18 terminal values,

- preference indicators for 18 instrumental values,

- empathy indicator,

- agreeableness indicator,

- directiveness indicator,

- Machiavellism indicator.

Pearson's linear correlation was used in the statistical analysis. This test allows to establish relationships between the indicated constructs, the existence of which was assumed in the hypotheses.

\section{Results}

The statistical analysis was initiated by establishing the relationship of among personality traits. It turned out that the indicators of empathy (the affective aspect of empathy was measured $)$ and agreeableness $(\mathrm{r}=0.31, \mathrm{p}<0.001)$ as well as directiveness and Machiavellianism ( $\mathrm{r}=0.21$, $\mathrm{p}<0.001)$ correlated positively with each other. The following regularity was observed: the higher the empathy, the higher the agreeableness, and, the higher the directiveness, the higher the Machiavellianism. Agreeableness correlated negatively with both directiveness $(\mathrm{r}=-0.34$, $\mathrm{p}<0.001)$ and Machiavellianism $(\mathrm{r}=-0.27, \mathrm{p}<0.001)$. This means that with the increase in agreeableness, directiveness and Machiavellianism decrease. The correlation coefficients between empathy and directiveness and Machiavellianism were also negative, but did not reach the required level of statistical significance. Hence, traits that have similar psychological characteristics are linked positively to each other, while those that differ in these characteristics are negative (although the relationships were not always statistically significant).

Next, it was determined what values are associated with the indicated personality traits. Tables 1 and 2 present the results of the statistical analysis of the relationship between personality traits and preferences of terminal and instrumental values. Negative correlations prove that a high indicator of a given personality trait is associated with high value preference, while positive correlations prove the opposite (a high indicator of a given trait is associated with low value preference). Such an interpretation results from the measurement of values using the ranking method.

The analysis of the relationship between empathy and values (cf. Tables 1 and 2) allows to conclude that people with higher indices of this trait appreciate more allocentric values. They attach more significance to such moral values as: "forgiving" (i7), "helpful" (i8), "honest" (i9), "loving" (i14) and "polite" (i16). Higher preference indices were also noted for the "equality" value ( $\mathrm{t} 2$ ) (it refers to the way in which relations between people are organized) and "salvation" (t11) (it has a religious character). A smaller value is ascribed to those idiocentric values that are selffocused and refer to hedonistic motivation, ie, "a comfortable life" (t1), "an exciting life" (t3) and "pleasure" (t10), contribute to individual success, ie "ambitious" (i1), "capable" (i3) and reflect the need for independence, ie "independent" (i11). Lower preference indices were also ascribed to the "clean" value (i5), which is not part of the idiocentric orientation.

Agreeableness is a personality trait with positive relationships with allocentric values (cf. Tables 1 and 2). Agreeable people, characterised by sensitivity and 
Table I Arithmetic Means of the Distributions of Measurement Results of All Variables. Correlation Coefficients Between Terminal Value Preference Indices and Personality Trait Indices

\begin{tabular}{|c|c|c|c|c|c|c|c|c|c|c|}
\hline \multirow[t]{2}{*}{ No. } & \multirow[t]{2}{*}{ Terminal Values } & \multirow{2}{*}{$\begin{array}{c}\text { Value Preferences } \\
t v=\end{array}$} & \multicolumn{2}{|c|}{$\begin{array}{l}\text { Empathy } \\
E=68.40\end{array}$} & \multicolumn{2}{|c|}{$\begin{array}{c}\text { Agreeableness } \\
\qquad A=30.43\end{array}$} & \multicolumn{2}{|c|}{$\begin{array}{l}\text { Directiveness } \\
\qquad=56.57\end{array}$} & \multicolumn{2}{|c|}{$\begin{array}{l}\text { Machiavellianism } \\
\qquad M=100.5 I\end{array}$} \\
\hline & & & $r=$ & $p$ & $r=$ & $p$ & $r=$ & $p$ & $r=$ & $p$ \\
\hline tl. & A Comfortable Life (id) & 11.24 & 0.22 & $<0.001$ & 0.20 & $<0.001$ & -0.21 & $<0.001$ & -0.13 & 0.021 \\
\hline $\mathrm{t} 2$. & Equality (al) & 10.55 & -0.11 & 0.056 & -0.11 & 0.058 & 0.20 & $<0.001$ & 0.13 & 0.023 \\
\hline $\mathrm{t} 3$. & An Exciting Life (id) & 14.50 & 0.12 & 0.033 & 0.16 & 0.004 & -0.21 & $<0.001$ & -0.19 & 0.001 \\
\hline $\mathrm{t} 4$. & Family Security (al) & 3.41 & 0.02 & 0.775 & -0.09 & 0.114 & 0.04 & 0.442 & 0.02 & 0.694 \\
\hline $\mathrm{t} 5$. & Freedom (id) & 7.47 & 0.08 & 0.127 & 0.13 & 0.015 & -0.06 & 0.289 & -0.05 & 0.349 \\
\hline t6. & Happiness (id) & 7.20 & 0.08 & 0.149 & 0.02 & 0.699 & 0.09 & 0.109 & -0.02 & 0.725 \\
\hline t7. & Inner Harmony (al) & 7.51 & -0.08 & 0.166 & -0.03 & 0.546 & 0.12 & 0.033 & 0.00 & 0.953 \\
\hline t8. & Mature Love (al) & 6.38 & -0.04 & 0.500 & 0.05 & 0.344 & -0.06 & 0.308 & 0.00 & 0.981 \\
\hline t9. & National Security (al) & 10.72 & 0.05 & 0.354 & -0.02 & 0.723 & 0.04 & 0.419 & 0.03 & 0.633 \\
\hline tlo. & Pleasure (id) & 13.27 & 0.10 & 0.079 & 0.07 & 0.188 & 0.01 & 0.823 & -0.10 & 0.063 \\
\hline tll. & Salvation (al) & 9.39 & -0.16 & 0.003 & -0.20 & $<0.001$ & 0.14 & 0.010 & 0.19 & 0.001 \\
\hline $\mathrm{t} 12$ & Self-Respect (id) & 7.15 & -0.01 & 0.927 & 0.08 & 0.165 & -0.21 & $<0.001$ & -0.06 & 0.249 \\
\hline $\mathrm{t} 13$. & A Sense of Accomplishment (id) & 11.57 & -0.03 & 0.639 & 0.01 & 0.804 & -0.10 & 0.072 & -0.10 & 0.079 \\
\hline $\mathrm{t} 14$. & Social Recognition (id) & 13.10 & 0.06 & 0.246 & 0.10 & 0.074 & -0.11 & 0.045 & -0.15 & 0.008 \\
\hline tI5. & True Friendship (al) & 7.75 & -0.08 & 0.154 & -0.12 & 0.037 & 0.03 & 0.567 & 0.02 & 0.671 \\
\hline tl6. & Wisdom (al) & 6.27 & -0.04 & 0.493 & -0.04 & 0.445 & -0.01 & 0.879 & 0.07 & 0.213 \\
\hline tl7. & A World at Peace (al) & 9.37 & -0.05 & 0.333 & -0.06 & 0.274 & 0.06 & 0.245 & 0.09 & 0.110 \\
\hline tl8. & A World of Beauty (id) & 14.05 & -0.06 & 0.292 & -0.04 & 0.522 & 0.09 & 0.101 & 0.10 & 0.066 \\
\hline
\end{tabular}

Notes: E - arithmetic mean for empathy; A -arithmetic mean for agreeableness; D -arithmetic mean for directiveness; $\mathrm{M}$-arithmetic mean for Machiavellianism; t I-t 8 eighteen terminal values; tv-arithmetic mean for terminal value ranks; (al) - allocentric values; (id) - idiocentric values; $r$ - Pearson's linear correlation coefficient; $P$ - level of statistical significance. Source: own elaboration.

a positive attitude towards people, prefer higher values that express this trait, ie "equality" (t2) and "true friendship" (t15). Positive relations with agreeableness are observed in the case of moral values and those that foster good emotional relations, ie "cheerful" (i4), "forgiving" (i7), "helpful" (i8), "loving" (i14), "obedient" (i15), "polite" (i16) and "responsible" (i17). The religious value of "salvation" (t11) also occupies a higher position in the system. All of them determine altruistic behaviour as well as willingness to give in and cooperate. At the same time, an increase in agreeableness is associated with a decline in the position in the system of idiocentric values - material and hedonistic-independent values, ie "a comfortable life" (t1), "an exciting life" (t3), "freedom" (t5), "social recognition" (t14), "independent" (i11) as well as the cognitive and stimulating values of personal success, ie, "broad-minded" (i2), "capable" (i3), "ambitious" (i1) and "courageous" (i6).

Persons with higher directiveness intensity value higher idiocentric, self-focused values (see Tables 1 and 2). They point to the importance of personal achievements, independence and authority, ie, "a sense of accomplishment" (t13), "ambitious" (i1), "independent" (i11), "courageous" (i6), "self-respect" (t12) and "social recognition" (t14). Higher preference rates are obtained by cognitive values, ie "broad-minded" (i2), "capable" (i3), "imaginative" (i10), "intellectual" (i12), and hedonistic values, ie "a comfortable life" (t1) and "an exciting life" (t3). At the same time, directive people manifest a lower preference for allocentric values relating to the well-being of other people. These are moral values: "forgiving" (i7), "helpful" (i8), "honest" (i9), "obedient" (i15), "polite" (i16), "responsible" (i17) and the values that condition non-conflicting relationships between people: "inner harmony" (i7), "cheerful" (i4) and "self-controlled" (i18). Also lower preference was ascribed to the values of "equality" ( $\mathrm{t} 2$ ) and "salvation" (t11), ie those related to egalitarianism and religiousness.

Relations between Machiavellianism and values are similar although they refer to a smaller number of values (see Tables 1 and 2). Persons with a higher intensity of Machiavellianism appreciate idiocentric values more. They manifest the need for achievements and social approval: "ambitious" (i1), "a sense of accomplishment" 
Table 2 Arithmetic Means of the Distributions of Measurement Results of All Variables. Correlation Coefficients Between Instrumental Value Preference Indices and Personality Trait Indices

\begin{tabular}{|c|c|c|c|c|c|c|c|c|c|c|}
\hline \multirow[t]{2}{*}{ No. } & \multirow[t]{2}{*}{ Instrumental Values } & \multirow{2}{*}{$\begin{array}{c}\text { Value Preferences } \\
\text { iv }=\end{array}$} & \multicolumn{2}{|c|}{$\begin{array}{l}\text { Empathy } \\
E=68.40\end{array}$} & \multicolumn{2}{|c|}{$\begin{array}{l}\text { Agreeableness } \\
\qquad A=30.43\end{array}$} & \multicolumn{2}{|c|}{$\begin{array}{l}\text { Directiveness } \\
\qquad D=56.57\end{array}$} & \multicolumn{2}{|c|}{$\begin{array}{l}\text { Machiavellianism } \\
\qquad M=|00.5|\end{array}$} \\
\hline & & & $r=$ & $p=$ & $r=$ & $p=$ & $r=$ & $p=$ & $r=$ & $p=$ \\
\hline il. & Ambitious (id) & 9.04 & 0.14 & 0.010 & 0.11 & 0.040 & -0.24 & $<0.001$ & -0.12 & 0.025 \\
\hline i2. & Broad-minded (id) & 9.64 & 0.05 & 0.350 & 0.13 & 0.022 & -0.14 & 0.010 & -0.14 & 0.012 \\
\hline i3. & Capable (id) & 12.25 & 0.15 & 0.006 & 0.16 & 0.005 & -0.19 & 0.001 & 0.02 & 0.706 \\
\hline i4. & Cheerful (id) & 9.79 & -0.06 & 0.250 & -0.10 & 0.063 & 0.12 & 0.031 & -0.01 & 0.853 \\
\hline i5. & Clean (al) & 11.06 & 0.16 & 0.003 & 0.07 & 0.237 & -0.07 & 0.197 & -0.14 & 0.015 \\
\hline i6. & Courageous (id) & 9.83 & 0.06 & 0.276 & 0.21 & $<0.001$ & -0.14 & 0.010 & -0.05 & 0.389 \\
\hline ¡7. & Forgiving (al) & 9.87 & -0.18 & 0.002 & -0.13 & 0.024 & 0.25 & $<0.001$ & 0.15 & 0.006 \\
\hline i8. & Helpful (al) & 7.99 & -0.18 & 0.001 & -0.27 & $<0.001$ & 0.27 & $<0.001$ & 0.17 & 0.003 \\
\hline i9. & Honest (al) & 5.72 & -0.13 & 0.018 & -0.07 & 0.195 & 0.16 & 0.004 & 0.16 & 0.005 \\
\hline ilo. & Imaginative (id) & 10.82 & 0.03 & 0.626 & 0.07 & 0.187 & -0.16 & 0.004 & -0.10 & 0.067 \\
\hline ill. & Independent (id) & 9.78 & 0.10 & $0.08 I$ & 0.16 & 0.005 & -0.21 & $<0.001$ & -0.07 & 0.226 \\
\hline il 2. & Intellectual (id) & 8.91 & 0.08 & 0.144 & 0.07 & 0.186 & -0.15 & 0.007 & -0.06 & 0.290 \\
\hline il 3. & Logical (id) & 11.13 & 0.03 & 0.578 & 0.03 & 0.647 & -0.05 & 0.386 & 0.02 & 0.708 \\
\hline il4. & Loving (al) & 4.26 & -0.13 & 0.017 & -0.11 & 0.055 & 0.08 & 0.145 & -0.00 & 0.976 \\
\hline il 5. & Obedient (al) & 15.49 & -0.01 & 0.884 & -0.10 & 0.083 & 0.17 & 0.003 & 0.14 & 0.010 \\
\hline il6. & Polite (al) & 9.81 & -0.11 & 0.047 & -0.22 & $<0.001$ & 0.15 & 0.007 & 0.05 & 0.349 \\
\hline il7. & Responsible (al) & 5.37 & -0.05 & 0.403 & -0.09 & 0.097 & 0.20 & $<0.001$ & 0.08 & 0.150 \\
\hline il 8. & Self-controlled (al) & 10.19 & -0.01 & 0.832 & -0.06 & 0.251 & 0.14 & 0.012 & 0.02 & 0.692 \\
\hline
\end{tabular}

Notes:E - arithmetic mean for empathy; A -arithmetic mean for agreeableness; D -arithmetic mean for directiveness; $M$-arithmetic mean for Machiavellianism; il-il 8 eighteen instrumental values; iv-arithmetic mean for instrumental value ranks; (al) - allocentric values; (id) - idiocentric values; $r$ - Pearson's linear correlation coefficient; $P$ - level of statistical significance. Source: own elaboration.

(t13) and "social recognition" (t14). They also have a cognitive character, ie "imaginative" (i10), "broadminded" (i2), and hedonistic, ie "a comfortable life" (t1), "pleasure" (t10) and "an exciting life" (t3). A higher preference is also observed for the "clean" value (i5), which, as indicated above, is not part of the idiocentric orientation. Machiavellianism is associated with a weaker acceptance of allocentric values. Lower positions in the system are occupied by moral values: "helpful" (i8), "obedient" (i15), "honest" (i9), "forgiving" (i7) and, as in the case of directiveness, the values of "equality" (t2) and "salvation" (t11). Machiavellists ascribe lower values to "a world of beauty" (t18) (beauty of nature and art).

The presented correlation coefficients are not high and some of them are at the border of statistical significance. This indicates - according to Pozzebon ${ }^{127}$ - that personality traits and values are overlapping, yet partially independent domains of individual differences. Ultimately, however, the following regularity is revealed in a systematic way: empathic and agreeable people (both personality traits are intercorrelated $\mathrm{r}=0.31, \mathrm{p}=<.001$ ) have a stronger acceptance of allocentric values and a weaker acceptance of idiocentric values. In the case of directive and Machiavellian people (both personality traits are correlated with each other at $\mathrm{r}=0.21, \mathrm{p}=<.001$ ), stronger acceptance of idiocentric values and weaker acceptance of allocentric values are observed. The results obtained are consistent with the hypotheses set out in this study.

\section{Summary}

The above analysis leads to the conclusion that the personality traits under consideration enter into numerous, yet at the same time, concordant relationships with value preferences. It should be noted that the system of values of empathic and agreeable people reveals an allocentric orientation which determines the tendency to abandon one's own perspective. These values reflect the need for integration and harmonious relationship between people, they encourage social sensitivity, benevolence, reconciliation, limitation of one's own desires and consideration of the needs of others, and they direct altruism and humanism. At the same time, the higher the empathy and agreeableness, the less importance is attached to idiocentric 
values. In the system of values of directive and Machiavellian people, on the other hand, an idiocentric orientation is revealed and it involves focusing on oneself and one's needs, rights and abilities. There exists a positive relationship with hedonistic and cognitive values reflecting the need for autonomy, achievement and dominance, and a negative relationship with allocentric values. Thus, each personality trait has its "axiological equivalent".

From the theoretical point of view, it seems important to determine the order of appearance of the analysed constructs and to establish which of them determine and which ones are determined during the development of an individual. It can be assumed that people shape their value systems in such a way as to adapt them to their personality traits, the self-representation they have made in their minds. Among others, Furnham ${ }^{42}$ and Luk and Bond ${ }^{32}$ presented this view. These authors believe that traits are primordial in relation to values and point to the mediating role of needs: individual differences predispose people to different needs which have an impact on the differentiation of value acceptance. This type of explanation seems likely when one considers the biological background of traits (McCrae, Costa; ${ }^{87}$ cf. Roccas et al. ${ }^{26}$ Olver, Mooradian $^{27}$ ) and an abstract nature of values. The creation of conceptual representation of a value is a relatively late phenomenon in ontogenesis, as the necessary condition for shaping abstract concepts is the appearance of formal thinking. In such an approach, personality traits "experienced" by an individual become one of the factors influencing the organization of values within the system. They are biological and thus primordial. Another explanation of causal relationships in the development of the analysed constructs was proposed by Roccas et al. ${ }^{26}$ They paid attention to cultural determinants of value systems and emphasized their influence on shaping personality traits: value preferences induce behaviours consistent with values, and on the basis of behaviours an individual can infer about their traits. This also explains why allocentrics exist in collective cultures, and idiocentrics in individualistic cultures. The relationship between personality traits and values can also be explained by "thirdparty" factors, such as inborn temperament that determines the parallel development of both constructs. ${ }^{26}$

The explanations given above are not contradictory, but rather complementary to each other. The fact that biological characteristics guide the development of value systems does not mean that a value system is independent of social, including cultural, influences. On the other hand, the fact that traits determine the development of a value system does not mean that a value system cannot contribute to modifying personality traits. Both of these constructs may also be based on temperamental determinants and enter into mutual relations during their creation. It is also possible that other variables - for example, needs - mediate in establishing a relationship between personality and values, and both constructs - as indicated by Parks et al. ${ }^{25,40}-$ simultaneously affect motivation and are predictors of behaviour. Although personality traits and values are stable, a possible change of the former has a greater impact on the latter than conversely. ${ }^{28}$

The description of nature and the way in which traits and values are related facilitates the understanding of basic aspects of human functioning. It can also help to explain human otherness and reduce errors in predicting behaviour. Having stated that, it seems convincing to follow the interpretation which assumes at the core of established relationships there lies a psychological mechanism that fosters the development of the Self in subjectively positive categories. Differences in the degree of positive selfesteem are connected (among other things) with the ability to organize various elements of knowledge about the Self on the basis of content consistency. At the same time, the positive image of the Self is sustained by acting in accordance with values, in different situations and at different times. ${ }^{2}$ The concordance of behaviour with values is conditioned by many factors. However, it seems more likely when personality traits facilitate a behavioural expression of values.

The above analyses also indicate some limitations in shaping value systems during the socialization process. Personality can influence the development of the value system during the acquisition of social experiences. For example, an empathic child may appreciate the "helpful" more than the "capable" value, even though parents consistently pointed out the importance of the latter. This is because the "helpful" value is consistent with the personality trait of empathy. On the other hand, values can mitigate the expression of personality traits in behaviour. For example, if someone is carefree, they may behave differently when they start a family. Concern for it is related to the value of "family security". In general, value-based behaviour is subject to greater cognitive control. Thus, one may be predisposed to be egoistic (a trait), but egoism does not have to be a permanent determinant of their functioning. 


\section{Limitation}

The representatives of the social sciences attach great importance to values (as a construct explaining human functioning), but the way they are measured is controversial. In this research, the RVS was used. When creating this tool, Rokeach made the assumption that behaviour is determined by the relative rather than absolute importance of values and, therefore, the most adequate method is ranking. However, this method forces individuals to produce a value system even when no such system actually exists. The relationships between multiple values then assume the form of horizontal relationships based on equivalence relations. This way of obtaining indicators may (although not necessarily) affect the correlation coefficients. It is therefore advisable to repeat the survey using a tool based on estimating values (rather than ranking them). The authors intend to repeat the survey and use The Schwartz Portrait Value Questionnaire (PVQ-R3). A specific feature of this tool is also that Schwartz does not use abstract value concepts.

\section{Declaration by Authors of the Nature of Research - Ethical Issues}

The study was non-interventional in nature and did not require permission from the Ethics Committee. The research does not fall within the field of clinical psychology. Neither is it of a clinical nature. This type of research does not in any way threaten the well-being of the people involved. The respondents were informed in advance that the research concerns beliefs about themselves. The respondents gave verbal consent in the presence of witnesses. They could resign from participation at any time. The survey was conducted during a 2.5-hour meeting (groups of 20-30 people). The respondents answered the questions included in the questionnaires. Handing out of the next questionnaire was preceded by a 15 -minute break. The survey was anonymous and the participation in it was voluntary. The survey was conducted in accordance with the Declaration of Helsinki.

\section{Author Contributions}

In recent years, researchers have focused primarily on the analysis of values in a cultural context. The result of this work was (among other things) the development of the so-called cultural world map. In the research the authors paid less attention to the variables that characterise an individual. Undoubtedly, the similarity of experiences - including cultural ones leads to similarities in the field of axiology. On the other hand, a person strives to integrate value-related information into distinct cognitive schemes and independently defines their meaning. In doing so, he/she takes into account his/her personality traits. The diagnosis of the relationship between values and personality traits is important from a theoretical point of view because it allows us to determine how knowledge about the I is organised. It is also of practical importance: it explains the complexity of the socialisation process and is helpful in predicting human behaviour.

\section{Disclosure}

The authors declare no conflicts of interest in this work.

\section{References}

1. Higgs M, Lichtenstein S. Exploring the "jingle fallacy": a study of personality and values. J Gen Manag. 2010;36(1):43-61. doi:10.1177/030630701003600103

2. Rokeach M. The Nature of Human Values. New York: Free Press; 1973.

3. Rokeach M. From individual to institutional values: with special reference to the values of science. In: Rokeach $M$, editor. Understanding Human Values. New York: Free Press; 1979:47-70.

4. Schwartz SH. Individualism-collectivism. Critique and proposed refinements. J Cross Cult Psychol. 1990;21(2):139-157. doi:10.1177/0022022190212001

5. Schwartz SH. Universals in the content and structure of values: theoretical advances and empirical tests in 20 countries. In: Zanna MP, editor. Advances in Experimental Social Psychology (T. 25). Orlando, FL: Academic Press; 1992:1-65.

6. Rohan MJ. A rose by any name? The values construct. Pers Soc Psychol Rev. 2000;4(3):255-277. doi:10.1207/ S15327957PSPR0403 4

7. Cieciuch J. Exploring the complicated relationship between values and behaviour. In: Roccas S, Sagiv L, editors. Values and Behavior. Taking a Cross-Cultural Perspective. Cham: Springer International Publishing AG; 2017:237-247. doi:10.1007/9783-319-56352-7 11

8. Skimina E, Cieciuch J, Fajkowska M. Explaining everyday behaviours and situational context by personality metatraits and higher-order values. Eur J Pers. 2020;34(1):29-59. doi:10.1002/ per. 2230

9. Schwartz SH. Value priorities and behavior: applying a theory of integrated value systems. In: Seligman C, Olson JM, Zanna MP, editors. The Psychology of Values: The Ontario Symposium (T. 8). Mahwah, New Jersey: Lawrence Erlbaum Associates; 1996:1-24.

10. Schwartz SH. A theory of cultural value orientations: explication and applications. Comp Sociol. 2006;5(2-3):136-182. doi:10.1163/156913306778667357

11. Schwartz SH. Studying values: personal adventure, future directions. J Cross Cult Psychol. 2011;42(2):307-319. doi:10.1177/0022022110396925

12. Fischer R, Schwartz SH. Whence differences in value priorities? Individual, cultural, or artifactual sources. J Cross Cult Psychol. 2011;42(7):1127-1144. doi:10.1177/0022022110381429 
13. Fischer R. Personality, Values, Culture: An Evolutionary Approach. Culture and Psychology. Cambridge: Cambridge University Press; 2017. doi:10.1017/9781316091944

14. Cieciuch J, Schwartz SH. Values and human being. In: van Zomeren M, Dovidio JF, editors. The Oxford Handbook of Human Essence. Oxford: Oxford University; 2017.

15. Ponikiewska K, Cieciuch J, Strus W. In search of convergence between the main dimensions of interpersonal and basic human values in the context of personality traits. Pers Individ Dif. 2020;162:110003. doi:10.1016/j.paid.2020.110003

16. Czerniawska M, Dolata E. Makiaweliści - dlaczego "prawie zawsze zwyciężają"? Psychologia Rozwojowa. 2004;9 (1):105-118.

17. Czerniawska M, Dolata E. Osobowościowe uwarunkowania systemów wartości. Psychologia Rozwojowa. 2005;10 (2):123-134.

18. Czerniawska M, Dolata E. Systemy wartości w kontekście zmiennych osobowościowych. Psychologia Rozwojowa. 2006;11 (4):103-114.

19. Goldberg LR. The structure of phenotypic personality traits. $A m$ Psychol. 1993;48(1):26-34. doi:10.1037/0003-066X.48.1.26

20. McCrae RR, Costa PT Jr. A five-factor theory of personality. In: Pervin LA, Oliver P, editors. Handbook of Personality Theory and Research. New York: Guilford Press; 1999:139-153.

21. Dollinger SJ, Leong FT, Ulicni S. On traits and values: with special reference to openness to experience. J Res Pers. 1996;30 (1):23-41. doi:10.1006/jrpe.1996.0002

22. Balliet D, Joireman J, Daniels D, George-Falvy J. Empathy and the Schwartz value system: a test of an integrated hypothesis. Individ Differ Res. 2008;6(5):269-279.

23. Caprara GV, Alessandri G, Eisenberg N. Prosociality: the contribution of traits, values, and self-efficacy beliefs. J Pers Soc Psychol. 2012;102(6):1289-1303. doi:10.1037/a0025626

24. Bilsky W, Schwartz SH. Values and personality. Eur J Pers. 1994;8(3):163-181. doi:10.1002/per.2410080303

25. Parks L, Guay RP. Personality, values, and motivation. Pers Individ Dif. 2009;47(7):675-684. doi:10.1016/j.paid. 2009.06.002

26. Roccas S, Sagiv L, Schwartz SH, Knafo A. The Big Five personality factors and personal values. Pers Soc Psychol Bull. 2002;28 (6):789-801. doi:10.1177/0146167202289008

27. Olver JM, Mooradian TA. Personality traits and personal values: a conceptual and empirical integration. Pers Individ Dif. 2003;35 (1):109-125. doi:10.1016/S0191-8869(02)00145-9

28. Fetvadjiev VH, He J. The longitudinal links of personality traits, values, and well-being and self-esteem: a Five study of nationally representative sample. J Pers Soc Psychol. 2019;117(2):448-464. doi:10.1037/pspp0000212

29. Oleś P. Wartościowanie a Osobowość. Lublin: Redakcja Wydawnictw KUL; 1989.

30. Rim Y. Importance of values according to personality, intelligence, and sex. Pers Individ Dif. 1984;5(2):245-246. doi:10.1016/0191-8869(84)90058-8

31. Czerniawska M. Inteligencja a System Wartości. Białystok: Trans Humana; 1995.

32. Luk CL, Bond MH. Personality variation and values endorsement in Chinese university students. Pers Individ Dif. 1993;14 (3):429-473. doi:10.1016/0191-8869(93)90312-Q

33. Yik MSM, Tang CS. Linking personality and values: the importance of a culturally relevant personality scale. Pers Individ Dif. 1996;21(5):767-774. doi:10.1016/0191-8869(96)00114-6

34. Herringer LG. Relating values and personality traits. Psychol Rep. 1998;83(3):953-954. doi:10.2466/pr0.1998.83.3.953

35. Wolfradt U, Dalbert C. Personality, values, and belief in just world. Pers Individ Dif. 2003;35(8):61-73. doi:10.1016/S01918869(03)00040-0
36. Aluja A, Garcia LF. Relationships between Big Five personality factors and values. Soc Behav Pers. 2004;32(7):619-626. doi:10.2224/sbp.2004.32.7.619

37. De Raad B, Van Oudenhoven PJ. Factors values in the Dutch language and their relationship to factors of personality. Eur J Pers. 2008;22(2):81-108. doi:10.1002/per.667

38. Haslam N, Whelan J, Bastian B. Big Five traits mediate associations between values and subjective well-being. Pers Individ Dif. 2009;46(1):40-42. doi:10.1016/j.paid.2008.09.001

39. Sun P, Shang S. Personality traits and personal values of servant leaders. Leadership Org Dev J. 2019;40(2):177-192. doi:10.1108/ LODJ-11-2018-0406

40. Parks-Leduc L, Feldman G, Bar A. Personality traits and personal values: a meta-analysis. Pers Soc Psychol Rev. 2015;19(1):3-29. doi: $10.1177 / 1088868314538548$

41. Grankvist G, Kajonius P. Personality traits and values: a replication with a Swedish sample. Int J Pers Psychol. 2015;1(1):8-14.

42. Furnham A. Personality and values. Pers Individ Dif. 1984;5 (4):483-485. doi:10.1016/0191-8869(84)90018-7

43. Saroglou V, Muñoz-García A. Individual differences in religion and spirituality: an issue of personality traits and/or values. $J$ Sci Study Relig. 2008;47(1):83-101. doi:10.1111/j.14685906.2008.00393.x

44. Myyry L, Helkama K. University students' value priorities and emotional empathy. Educ Psychol. 2001;21(1):25-40. doi:10.1080/01443410123128

45. Myyry L, Juujarvi S, Pesso K. Empathy, perspective taking and personal values as predictors of moral schemas. J Educ. 2010;39 (2):213-233

46. Persson BN, Petri J, Kajonius PJ. Empathy and universal values explicated by the empathy-altruism hypothesis. J Soc Psychol. 2016;156(6):610-619. doi:10.1080/00224545.2016.1152212

47. Silfver M, Helkama K, Lonnqvist JE, Verkasalo M. The relation between value priorities and proneness quilt, shame, and empathy. Motiv Emot. 2008;32:69-80. doi:10.1007/s11031-008-9084-2

48. Markus H. Self-schemata and processing information about the self. J Pers Soc Psychol. 1977;35(2):63-78. doi:10.1037/00223514.35.2.63

49. Kihlstrom JF, Cantor N. Mental representations self. In: Berkowitz L, editor. Advances in Experimental Social Psychology. San Diego, CA: Academic Press; 1984:1-47.

50. Campbell JD, Trapnell PD, Heine SJ, Katz IM, Lavallee LF, Lehman DR. Self-concept clarity: measurement, personality correlates, and cultural boundaries. J Pers Soc Psychol. 1996;70 (1):141-156. doi:10.1037/0022-3514.70.1.141

51. Campbell JD, Assanand S, Paula AD. The structure of the self-concept and its relation to psychological adjustment. $J$ Pers. 2003;71(1):115-140. doi:10.1111/1467-6494.t01-1-00002

52. Crocetti E, Van Dijk MPA. Self-concept clarity. In: Levesque RJR, editor. Encyclopedia of Adolescence. Switzerland: Springer International Publishing; 2016. Available from: https://link.springer.com/referenceworkentry/10.1007/9783-319-32132-5_808-1. Accessed April 14, 2021.

53. Campbell JD. Self-esteem and clarity of the self-concept. J Pers Soc Psychol. 1990;59(3):538-549. doi:10.1037/0022-3514.59.3.538

54. $\mathrm{Wu} \mathrm{CH}$. The relationship between attachment style and self-concept clarity: the mediation effect of self-esteem. Pers Individ Dif. 2009;47:42-46. doi:10.1016/j.paid.2009.01.043

55. Light AE. Self-concept clarity, self-regulation, and psychological well-being. In: Lodi-Smith J, DeMarree KG, editors. Self-Concept Clarity: Perspectives on Assessment, Research, and Applications. Cham: Springer; 2017:177-193.

56. Baumeister RF. Understanding the inner nature of low selfesteem: uncertain, fragile, protective, and conflicted. In: Baumeister RF, editor. Self-Esteem: The Puzzle of Low SelfRegard. New York: Plenum; 1993:201-218. 
57. Baumeister RF. The nature and structure of the self: an overview. In: Baumeister R, editor. The Self in Social Psychology. Philadelphia, PA: Psychology Press (Taylor \& Francis); 1999:1-20.

58. Tice DM. The social motivations of people with low self-esteem. In: Baumeister RF, editor. Self-Esteem: The Puzzle of Low SelfRegard. New York: Plenum; 1993:37-54.

59. DeMarree KG, Rios K. Understanding the relationship between self-esteem and self-clarity: the role of desired self-esteem. $J$ Exp Soc Psychol. 2014;50:202-209. doi:10.1016/j.jesp.2013.10.003

60. Wong AE, Vallacher RR, Nowak A. Intrinsic dynamics of state self-esteem: the role of self-concept clarity. Pers Individ Dif. 2016;100:167-172. doi:10.1016/j.paid.2016.05.024

61. DeMarree KG, Bobrowski ME. Structure and validity of selfconcept clarity measures. In: Lodi-Smith J, DeMarree KG, editors. Self-Concept Clarity: Perspectives on Assessment, Research, and Applications. Cham: Springer; 2017:1-17.

62. Lodi-Smith J, Crocetti E. Self-concept clarity across the lifespan. In: Lodi-Smith J, DeMarree KG, editors. Self-Concept Clarity: Perspectives on Assessment, Research, and Applications. Vol. 2017. Cham: Springer; 2017:67-84.

63. Krueger JI, Vohs KD, Baumeister RF. Is the allure of self-esteem a mirage after all? Am Psychol. 2008;63(1):64-65. doi:10.1037/ 0003-066X.63.1.64

64. Davis MH. Empathic concern and the muscular dystrophy telethon: empathy as multidimensional construct. Pers Soc Psychol Bull. 1983;9(2):223-229. doi:10.1177/0146167283092005

65. Davis MH. Empathy. A Social Psychological Approach. New York: Routledge; 1996.

66. Hoffman ML. Interaction of affect and cognition in empathy. In: Izard CE, Kagan J, Zajonc RB, editors. Emotions, Cognition, and Behavior. Cambridge: Cambridge University Press; 1984:103-131.

67. Batson CD. The Altruism Question: Toward a SocialPsychological Answer. Hillsdale, NJ: Lawrence Erlbaum Associates; 1991.

68. Batson CD. These things called empathy: eight related but distinct phenomena. In: Decety J, Ickes W, editors. The Social Neuroscience of Empathy. Cambridge, MA: MIT Press; 2009:3-30

69. Eisenberg N, Miller PA. The relation of empathy to prosocial and related behavior. Psychol Bull. 1987;101(1):91-119. doi:10.1037/ 0033-2909.101.1.91

70. Eisenberg N, Eggum ND. Empathic responding: sympathy and personal distress. In: Decety J, Ickes W, editors. The Social Neuroscience of Empathy. Cambridge, MA: MIT Press; 2009:71-83.

71. Davis MD, Mitchell KV, Hall JA, Lothert J, Snapp T, Meyer M. Empathy, expectations, and situational preferences: personality influences on the decision to participate in volunteer helping behaviors. $J$ Pers. 1999;67(3):469-501. doi:10.1111/14676494.00062

72. Leith KP, Baumeister RF. Empathy, shame, guilt, and narratives of interpersonal conflicts: guilt-prone people are better at perspective taking. $J$ Pers. 1998;66(1):1-37. doi:10.1111/14676494.00001

73. Batson CD, Lishner DA, Stocks EL. The empathy-altruism hypothesis. In: Schroder DA, Graziano WG, editors. The Oxford Handbook of Prosocial Behavior. New York, NY: Oxford University Press; 2015:259-281.

74. Decety J, Meidenbauer KL, Cowell JM. The development of cognitive empathy and concern in preschool children: a behavioral neuroscience investigation. Dev Sci. 2018;21 (3):1-12. doi:10.1111/desc. 12570

75. McAuliffe WHB, Carter EC, Berhane J, Snihur AC, McCullough ME. Is empathy the default response to suffering? A Meta-analytic evaluation of perspective taking's effect on empathic concern. Pers Soc Psychol Rev. 2020;24(2):141-162. doi: $10.1177 / 1088868319887599$
76. Knafo A, Uzefovsky F. Variation in empathy: the interplay of genetic and environmental factors. In: Legerstee M, Haley DW, Bornstein MH, editors. The Infant Mind: Origins of the Social Brain. New York: Guilford Press; 2013:97-122.

77. Uzefovsky F, Knafo-Noam A. Empathy development throughout the life span. In: Sommerville JA, Decety J, editors. Social Cognition: Development Across the Life Span. New York: Routledge; 2017:71-97.

78. Davis MH, Luce C, Kraus SJ. The heritability of characteristics associated with dispositional empathy. J Pers. 1994;62 (3):369-391. doi:10.1111/j.1467-6494.1994.tb00302.x

79. Eisenberg N, Fabes RA. Emotion, regulation, and the development of social competence. In: Clark MS, editor. Review of Personality and Social Psychology: Emotion and Social Behavior. Newbury Park, CA: Sage; 1992:119-150.

80. Eisenberg N, Fabes RA, Murphy B, et al. The relations of emotionality and regulation to dispositional and situational empathy-related responding. J Pers Soc Psychol. 1994;66 (4):776-797. doi:10.1037/0022-3514.66.4.776

81. Spinrad TL, Losoya SH. The relations of parental affect and encouragement to children's moral emotions and behavior. J Moral Educ. 1999;28:323-338. doi:10.1080/030572499103115

82. Mikulincer M, Gillath O, Halevy V, Avihou N, Avidan S, Eshkoli N. Attachment theory and reactions to others' needs: evidence that activation of the sense of attachment security promotes empathic responses. J Pers Soc Psychol. 2001;81 (6):1205-1224. doi:10.1037/0022-3514.81.6.1205

83. Batson CD, Ahmad N, Stocks EL. Benefits and liabilities of empathy-induced altruism. In: Miller AG, editor. The Social Psychology of Good and Evil. New York: The Guilford Press; 2004:359-385.

84. Hoffman ML. Empathy and Moral Development: Implications for Caring and Justice. Cambridge: Cambridge University Press; 2000. doi:10.1017/CBO9780511805851

85. Costa PT, McCrae RR. Revised NEO Personality Inventory (NEO $P I-R)$ and NEO Five-Factor Inventory (NEO-FFI). Vocational Manual. Odessa: Psychological Assessment Ressources; 1992.

86. McCrae RR. The Five-Factor Model of personality traits: consensus and controversy. In: Corr P, Matthews G, editors. The Cambridge Handbook of Personality Psychology. Cambridge, England: Cambridge University Press; 2009:148-161.

87. McCrae RR, Costa PT Jr. Introduction to the empirical and theoretical status of the Five-Factor Model of personality traits. In: Widiger TA, Costa PT Jr, editors. Personality Disorders and the Five-Factor Model of Personality 3rd. Washington, DC: American Psychological Association; 2013:15-27.

88. Graziano WG, Eisenberg N. Agreeableness: a dimension of personality. In: Hogan R, Johnson JA, Briggs SR, editors. Handbook of Personality Psychology. San Diego: Academic Press; 1997:795-824.

89. Graziano WG, Habashi MM, Sheese BE, Tobin RM. Agreeableness, empathy, and helping: a person $\times$ situation perspective. $J$ Pers Soc Psychol. 2007;93(4):583-599. doi:10.1037/0022-3514.93.4.583

90. Gleason KA, Jensen-Campbell LA, Richardson DS. Agreeableness as predictor of aggression in adolescence. Aggress Behav. 2004;30(1):43-61. doi:10.1002/ab.20002

91. Ode S, Robinson MD. Can agreeableness turn gray skies blue? A role for agreeableness in moderating neuroticism-linked dysphoria. $J$ Soc Clin Psychol. 2009;28(4):436-462. doi:10.1521/jscp.2009.28.4.436

92. Realo A, Luik M. On the relationship between collectivism and empathy in the context of personality traits. Trames. 2002;6(56/ 51):218-233.

93. Del Barrio V, Aluja A, Garcia LF. Relationship between empathy and the Big Five personality traits in a sample of Spanish adolescents. Soc Behav. 2002;32(7):677-680. doi:10.2224/ sbp.2004.32.7.677 
94. Kalshoven K, Den Hartog D, De Hoogh A. Ethical leader behavior and Big Five factors of personality. J Bus Ethics. 2011;100 (2):349-366. doi:10.1007/s10551-010-0685-9

95. Chowdhury MS, Amin MN. Personality and students' academic achievement: interactive effects of conscientiousness and agreeableness on students' performance in principles of economics. Soc Behav Pers. 2006;34(4):381-388. doi:10.2224/ sbp.2006.34.4.381

96. Ray JJ. Authoritarianism, dominance and assertiveness. J Pers Assess. 1981;45(4):390-397. doi:10.1207/s15327752jpa4504_8

97. Brzozowski P. Skala Dyrektywności Johna. J. Raya. Warszawa: Pracownia Testów Psychologicznych Polskiego Towarzystwa Psychologicznego; 1997.

98. Ray JJ. Authoritarian tolerance. J Soc Psychol. 1980;111:303-304.

99. Ray JJ. Authoritarianism and hostility. J Soc Psychol. 1980;112:307-308. doi:10.1080/00224545.1980.9924335

100. Pratto F, Sidanius J, Stallworth LM, Malle BF. Social dominance orientation: a personality variable predicting social political attitudes. J Pers Soc Psychol. 1994;67(4):741-763. doi:10.1037/ 0022-3514.67.4.741

101. Madison G, Aasa U, Wallert J, Woodley MA. Feminist activist women are masculinized in terms of digit-ratio and social dominance: a possible explanation for the feminist paradox. Front Psychol. 2014;5:1011. doi:10.3389/fpsyg.2014.01011

102. Sidanius J, Pratto F. Social Dominance: An Intergroup Theory of Social Hierarchy and Oppression. New York: Cambridge University Press; 2012.

103. Ray JJ. Achievement motivation as source of racism, conservatism and authoritarianism. J Soc Psychol. 1984;123(1):21-28. doi:10.1080/00224545.1984.9924509

104. Paulhus DL, Williams KM. The Dark Triad of personality: narcissism, Machiavellianism, and psychopathy. J Res Pers. 2002;36 (6):556-563. doi:10.1016/S0092-6566(02)00505-6

105. Jonason PK, Strosser GL, Kroll CH, Duineveld JJ, Baruffi SA. Valuing myself over others: the Dark Triad traits and moral and social values. Pers Individ Dif. 2015;81:102-106. doi:10.1016/j. paid.2014.10.045

106. Moor L, Anderson JR. A systematic literature review of the relationship between dark personality traits and antisocial online behaviours. Pers Individ Dif. 2019;144:40-55. doi:10.1016/j. paid.2019.02.027

107. Christie R, Geis F. Studies in Machiavellism. New York: Academic Press; 1970.

108. Fehr B, Samsom D, Paulhus DL. The construct of Machiavellianism. Twenty years later. In: Spielberger CD, Butcher JN, editors. Advances in Personality Assessment. T. 9. Hillsdale, NJ: Erlbaum; 1992:77-116.

109. Jones DN, Paulhus DL. Machiavellianism. In: Leary MR, Hoyle RH, editors. Handbook of Individual Differences in Social Behavior. New York, NY: Guilford Press; 2011:93-108.

110. Drwal R, Brzozowski P. Skala Makiawelizmu (Mach V) R. Christiego i F.L. Geis; problemy rzetelności i trafności. In: Drwal RŁ, editor. Adaptacja Kwestionariuszy Osobowości. Warszawa: PWN; 1995:184-196.

111. McHoskey JW, Worzel W, Szyarto C. Machiavellianism and psychopathy. J Pers Soc Psychol. 1998;74(1):192-210. doi:10.1037/0022-3514.74.1.192

112. Shepperd JA, Socherman RE. On the manipulative behavior of low Machiavellians: feigning incompetence to "sandbag" an opponent's effort. J Pers Soc Psychol. 1997;72(6):1448-1459. doi:10.1037/0022-3514.72.6.1448
113. Wiggins JS, Broughton R. The interpersonal circle: a structural model for the integration of personality research. In: Hogan R, Jones WH, editors. Perspectives in Personality, (T. 1). Greenwich, CT: JAI Press; 1985:1-47.

114. Gunnthorsdottir A, McCabe K, Smith V. Using the Machiavellianism instrument to predict trustworthiness in a bargaining game. $J$ Econ Psychol. 2002;23(1):49-66. doi:10.1016/S0167-4870(01)00067-8

115. Wilson DS, Near D, Miller RR. Machiavellianism: a synthesis of evolutionary and psychological literatures. Psychol Bull. 1996;119(2):285-299. doi:10.1037/0033-2909.119.2.285

116. Czibor A, Vincze O, Bereczkei T. Feelings and motives underlying Machiavellian behavioural strategies: narrative reports in a social dilemma situation. Int J Psychol. 2014;49(6):519-524. doi:10.1002/ijop. 12077

117. Austin EJ, Farrelly D, Black C, Moore H. Emotional intelligence, Machiavellianism and emotional manipulation: does EI have a dark side? Pers Individ Dif. 2007;43(1):179-189. doi:10.1016/ j.paid.2006.11.019

118. Kuyumcu D, Dahling JJ. Constraints for some, opportunities for others? Interactive and indirect effects of machiavellianism and organizational constraints on task performance ratings. J Bus Psychol. 2014;29(2):301-310. doi:10.1007/s10869-013-9314-9

119. Kajonius PJ, Persson BN, Jonason PK. Hedonism, achievement, and power: universal values that characterize the Dark Triad. Pers Individ Dif. 2015;77:173-178. doi:10.1016/j.paid.2014.12.055

120. Triandis HC, Bontempo R, Villareal MJ, Asai M, Lucce N. Individualism and collectivism: cross-cultural perspectives on self-ingroup relationships. J Pers Soc Psychol. 1988;54 (2):323-338. doi:10.1037/0022-3514.54.2.323

121. Pervin LA. The Science of Personality. Oxford: Oxford University Press; 2003.

122. Cervone D. Personality architecture: within-person structures and processes. Ann Rev Psychol. 2005;56(1):423-452. doi:10.1146/ annurev.psych.56.091103.070133

123. Brzozowski P. Skala Wartości (SW). Polska Adaptacja Value Survey M. Rokeacha. Warszawa: Wydział Psychologii Uniwersytetu Warszawskiego; 1989.

124. Czerniawska M. Zmiany Wartości i Postaw Młodzieży w Okresie Przeobrażeń Ustrojowych - Kolektywizm versus Indywidualizm. Studium Interdyscyplinarne. Białystok: Wydawnictwo Politechniki Białostockiej; 2010.

125. Węgliński A. Trafność Kwestionariusza Rozumienia Empatycznego Innych Ludzi. In: Drwal R, editor. Techniki Kwestionariuszowe $w$ Diagnostyce Psychologicznej. Lublin: UMCS; 1987:63-80.

126. Zawadzki B, Strelau J, Szczepaniak P, Śliwińska M. Inwentarz Osobowości NEO-FFI Costy i McCrae. Warszawa: Pracownia Testów Psychologicznych Polskiego Towarzystwa Psychologicznego; 1998.

127. Pozzebon J Personality traits and personal values: an investigation into the importance of each in the prediction of behavior [Julie Pozzebon Master Thesis]. Department of Psychology Brock University; 2006. 


\section{Publish your work in this journal}

Psychology Research and Behavior Management is an international, peer-reviewed, open access journal focusing on the science of psychology and its application in behavior management to develop improved outcomes in the clinical, educational, sports and business arenas. Specific topics covered in the journal include: Neuroscience, memory and decision making; Behavior modification and management; Clinical

applications; Business and sports performance management; Social and developmental studies; Animal studies. The manuscript management system is completely online and includes a very quick and fair peer-review system, which is all easy to use. Visit http://www. dovepress.com/testimonials.php to read real quotes from published authors. 